\title{
Sistem Peringatan Awal Resiko Preeklampsia Pada Kehamilan Menggunakan Metoda Certainty Factor
}

\author{
Fitrilina $^{1 *}$, M. Albbi ${ }^{1}$, Indra Agustian ${ }^{1}$, Afriyastuti Herawati ${ }^{1}$, Nikki Aldi Massardi ${ }^{2}$ \\ ${ }^{1}$ Program Studi Teknik Elektro, Fakultas Teknik, Universitas Bengkulu \\ ${ }^{2}$ Program Studi Kedokteran, Fakultas Kedokteran, Universitas Bengkulu \\ *e-mail: fitrilina@unib.ac.id
}

\begin{abstract}
Abstrak - Angka kematian Ibu hamil (AKI) karena preeklampsia masih cukup tinggi di Indonesia umumnya dan provinsi Bengkulu khususnya. Belum ada metoda yang efektif untuk mencegah terjadinya preeklampsia, tetapi deteksi dini dapat menolong untuk penanganan dan pengobatan yang cepat dan tepat. Monitoring kondisi kehamilan sangat penting, tetapi pandemi COVID-19 menyebabkan ibu hamil tidak dianjurkan untuk ke fasilitas kesehatan. Oleh karena itu dirancang sistem monitoring kondisi kehamilan untuk deteksi dini preeklampsia menggunakan metoda Certainty Factor berbasis Android. Sistem ini terdiri dari alat ukur tekanan darah dan sistem pakar. Alat ukur tensimeter menggunakan sensor tekanan MPX5500, filter high pass butteworth dan mikrokontroller Arduino terhubung ke smartphone android melalui Bluetooth. Sistem pakar akan mendiagnosa ibu hamil beresiko preklampsia atau hipertensi dalam kehamilan tanpa resiko preklamsia. Alat ukur tekanan darah yang dirancang untuk mendukung sistem, bekerja dengan rata-rata selisih terhadap pengukuran tensimeter aneroid sebesar 7,05 $\mathrm{mmHg}$ dengan galat $6,24 \%$ pada tekanan sistolik dan $10,15 \mathrm{mmHg}$ dengan galat $13,13 \%$ pada tekanan diastolik. Hasil diagnosa sistem pakar memiliki akurasi sebesar 91,45\%. Sehingga dapat dikatakan bahwa sistem yang dirancang telah dapat digunakan.
\end{abstract}

Kata Kunci : Preklamsia, tensimeter, sistem pakar certainty factor

\begin{abstract}
The mortality rate for pregnant women due to preeclampsia is still quite high in Indonesia in general and Bengkulu province in particular. There is no effective method to prevent preeclampsia, but early detection can help for proper treatment. Monitoring the condition of pregnancy is very important but the COVID-19 pandemic has prevented pregnant women to go to health facilities. Therefore, a pregnancy condition monitoring system was designed for early detection of preeclampsia using the android-based Certainty Factor method. The system designed consists of a blood pressure measuring device and an expert system. The device uses an MPX5500 pressure sensor, highpass Butterworth filter and an Arduino connected to an android smartphone via Bluetooth. The expert system will diagnose that pregnant women are at risk of preeclampsia or hypertension in pregnancy without the risk of preeclampsia. The blood pressure measuring device works with an average difference to the aneroid sphygmomanometer of $7.05 \mathrm{mmHg}$ with an error of $6.24 \%$ at systolic pressure and $10.15 \mathrm{mmHg}$ with an error of $13.13 \%$ at diastolic pressure. The result of expert system diagnosis has an accuracy of $91.45 \%$. So it can be said that the designed system can be used
\end{abstract}

Keywords : Preeclampsia, Blood Pressure Device, Certainty Factor Method

\section{Pendahuluan}

Angka Kematian Ibu (AKI) dibawah 70 per 100.000 kelahiran hidup pada tahun 2030 menjadi target Sustainable Development Goals (SDG's) bidang kesehatan Indonesia [1]. Sejak tahun 2015 AKI di Indonesia bergerak lambat bahkan cenderung tidak beranjak di angka 305 kematian per 100.000 kelahiran hidup. AKI di Provinsi Bengkulu pada tahun 2015 masih di angka 162 kematian per 100.000 kelahiran hidup, kemudian perlahan menurun hingga angka 111 kematian pada tahun 2018 [2]. Tiga penyebab utama kematian ibu adalah perdarahan $30 \%$, hipertensi dalam kehamilan 25\%, dan infeksi $12 \%$ [3]. WHO memperkirakan negara berkembang memiliki kemungkinan kasus preklamsia tujuh kali lebih tinggi daripada Negara maju. Insiden preeklampsia di Indonesia adalah 128.273/tahun atau sekitar 5,3\%. Dalam dua decade ini, belum 
terlihat penurunan yang berarti terhadap kasus preklamsia[3]. Sementara, data dinas Kesehatan dan Lingkungan Hidup Provinsi Bengkulu menunjukan 25\%. Salah satu faktor yang melatarbelakangi kematian ibu, yakni terlambat mengetahui kondisi berbahaya dan melakukan tindakan. WHO 2017 menganjurkan agar ibu hamil memeriksakan kesehatan 8 kali dalam satu periode. Sedangkan di Indonesia hanya mengharuskan 4 kali kontrol kehamilan difasilitas kesehatan. Belum ada metode yang efektif untuk mencegah preklamsia tetapi deteksi awal dapat menolong agar dapat dilakukan pengobatan dan penangann yang tepat $[4,5,6,7]$. Oleh karena itu banyak penelitian mengembang sistem pakar untuk mendeteksi dini preklamsia diantaranya [4] dan [8]. Kebanyakan penelitian yang telah ada masih terbatas pada perancangan sistem pakar, belum terintegrasi dengan perangkat elektromedis. Sedangkan untuk analisa data pada sistem pakar selain membutuhkan data gejala yang dirasakan oleh ibu, juga memerlukan pemeriksaan tekanan darah ibu.

Oleh karena itu perlu dirancangan sistem monitoring kondsi kehamilan untuk deteksi dini preklamsia yang terintegrasi dengan perangkat elektromedis yaitu alat ukur tekanan darah berbasiskan Android. Dengan adanya sistem ini, ibu hamil dapat memeriksa diri sendiri dan menganalisa kondisi kehamilan untuk deteksi preeklampsia menggunakan smart phone Android sehingga dapat diketahui lebih awal beresiko preeklampsia atau tidak. Diharapkan sistem ini menjadi solusi tepat guna bagi ibu hamil untuk tetap di rumah saja memenuhi himbauan pemerintah dalam memutus rantai penyebaran pandemic covid-19 tetapi tetap dapat memonitor kondisi kehamilannya. Dengan adanya pemeriksaan secara rutin oleh ibu hamil terhadap kondisi kehamilan dan kemungkinan resiko preeklampsia maka diharapkan preeklampsia pada ibu hamil dapat dideteksi dan ditangani lebih awal, sehingga dapat mengurangi resiko kematian ibu karena preeklampsia

\section{Metode}

Pada penelitian ini dirancang sistem monitoring kondisi kehamilan untuk deteksi dini preeklampsia berbasis smartphone android. Gambar 1 menunjukan sistem yang dirancang.

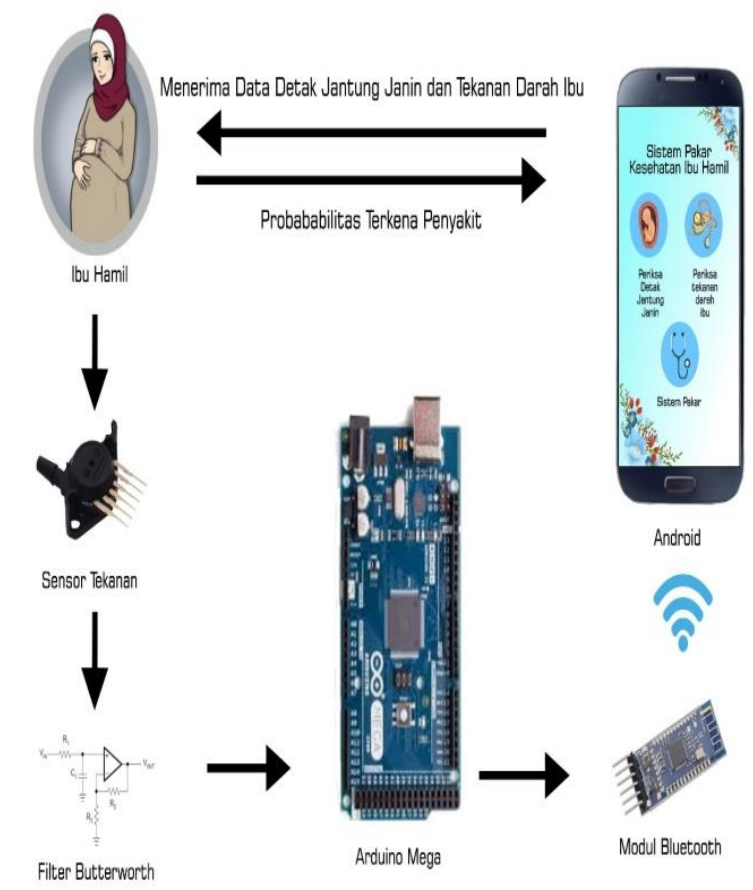

Gambar 1. Desain Rancang Bangun sistem deteksi dini Preklamsia menggunakan sistem pakar certainty factor

Sistem ini terdiri dari alat ukur tekanan darah dan sistem pakar preeklampsia. Alat ukur tekanan darah atau tensimeter digital dibuat dengan dengan metoda osilometrik menggunakan sensor tekanan dan filter high pass Butterworth. Hasil keluaran filter diproses pada arduino dan dilakukan konversi ke nilai mmHg. Nilai tekanan darah dalam satuan mmHG ditampilkan pada LCD dan aplikasi di smartphone android dengan koneksi via Bluetooth HC-05. Tensimeter yang dirancang dibandingkan dengan tensimeter digital dan tensimeter aneroid kemudian dihitung selisih dan galat pengukurannya. Sedangkan sistem pakar dirancang menggunakan metoda Certainty Factor pada smartphone android. Sistem pakar diuji menggunakan 35 kasus dengan cara membandingkan diagnosa dokter dan keputusan sistem. Jika keputusan sama maka dianggap benar jika keputusan beda maka dianggap salah.

\subsection{Perancangan Tensimeter Digital}

Tensimeter digital menggunakan sensor MPX 5500, filter High pass Butterworth dan arduino. Filter yang digunakan merupakan orde ke-4 dengan frekuensi cut off $1 \mathrm{~Hz}$. Diagram alir rancangan tensimeter digital seperti pada gambar 2 
dan rancangan filter yang digunakan seperti pada gambar 3 .

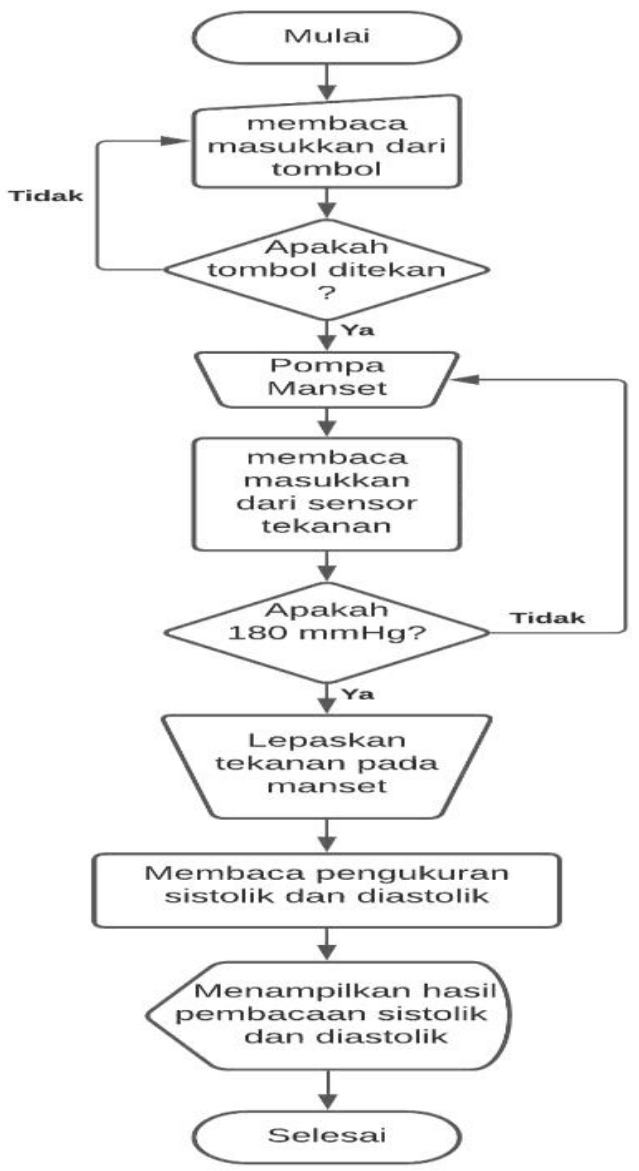

Gambar 2. Diagram Alir tensimeter digital

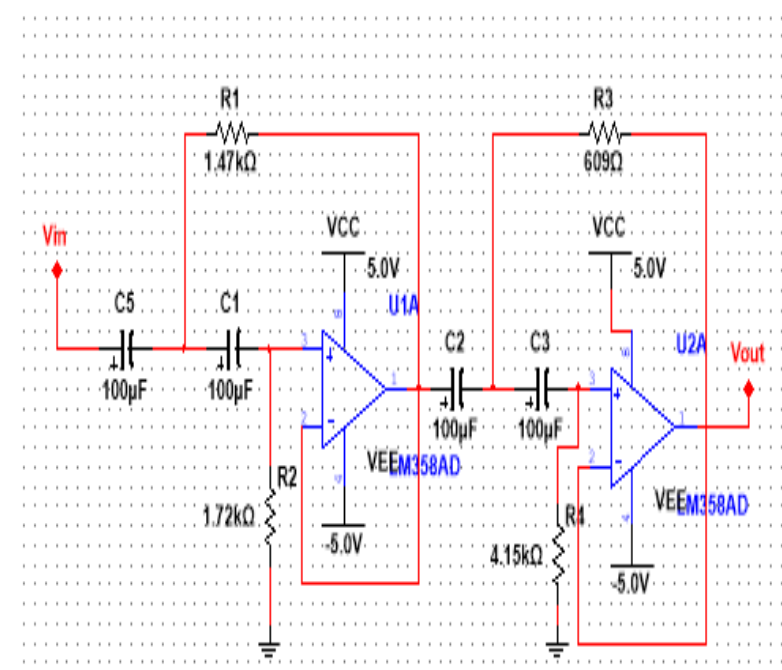

Gambar 3. Rangkaian High Pass Filter.

Berdasarkan sinyal hasil keluaran filter kemudian ditentukan nilai tekanan sistolik dan tekanan diastoliknya. Posisi tekanan sistolik didapatkan ketika ditemukan pertama kali magnitude sinyal $\geq 0,7$ kali magnitude maksimal sinyal dan terjadi sebelum magnitude maksimal. Posisi tekanan diastolik didapatkan pada magnitude sinyal terakhir yang masih bernilai $\geq$ 0,5 kali magnitude maksimal sinyal dan terjadi setelah magnitude maksimal. Nilai ini kemudian dikonversi ke mmHg dengan persamaan 1 .

$$
\text { Tekanan }=\frac{\left(\frac{V o u t}{V s}-0.04\right)}{0.0018} \times 7,500617 \mathrm{mmHg}
$$

2.2 Perancangan sistem pakar preeklampsia menggunakan metoda Certainty Factor

Nilai CF didapat dari Qualitatif Term yang diberikan pakar. Nilai Qualitatif Term dan nilai Certainty Factor menggunakan table 1

\section{Tabel .1 Nilai Interpretasi CF[9].}

\begin{tabular}{|l|l|}
\hline Qualitatif Term & Certainty Factor \\
\hline Pasti tidak & -1.0 \\
Hampir pasti tidak & -0.8 \\
Kemungkinan besar tidak & -0.6 \\
Mungkin tidak & -0.4 \\
Tidak tahu/tidak yakin & -0.2 to 0.2 \\
Mungkin & 0.4 \\
Kemungkinan Besar & 0.6 \\
Hampir pasti & 0.8 \\
pasti & 1.0 \\
\hline
\end{tabular}

Kombinasi nilai Certainty Factor memenuhi aturan yang berlaku menurut McAllister seperti pada Tabel 2 .

Tabel 2 Aturan-aturan McAllister. [9]

\begin{tabular}{|c|l|c|}
\hline No & \multicolumn{1}{|c|}{ Kondisi Aturan } & Rumus \\
\hline 1 & $\begin{array}{l}\text { Apabila kedua nilai CF } \\
\text { positif }(++)\end{array}$ & $\begin{array}{c}\mathrm{CFc}\left(\mathrm{CF}_{1}, \mathrm{CF}_{2}\right)=\mathrm{CF}_{1} \\
+\mathrm{CF}_{2} *\left(1-\mathrm{CF}_{1}\right)\end{array}$ \\
\hline 2 & negatif $(--)$ & $\mathrm{CFc}\left(\mathrm{CF}_{1}, \mathrm{CF}_{2}\right)=\mathrm{CF}_{1}$ \\
\hline 3 & $\begin{array}{l}\mathrm{C} \mathrm{CF}_{2} *\left(1+\mathrm{CF}_{1}\right) \\
\text { Apabila salah satu nilai }\end{array}$ & $\mathrm{CFc}=\frac{C F_{1}+C F_{2}}{1-\min \left(\left|C F_{1}\right|,\left|C F_{2}\right|\right)}$ \\
\hline
\end{tabular}


Setelah wawancara dengan tiga pakar yaitu dokter spesialis kandungan (SpOG) maka didapatkan daftar faktor resiko dan gejala preeklampsia beserta nilai certainty factor-nya seperti pada tabel 3 .

Tabel 3. Daftar faktor resiko dan gejala beserta nilai $\mathrm{CF}$

\begin{tabular}{|c|c|c|c|}
\hline No & Parameter & Pilihan Parameter & $\begin{array}{l}\text { Nilai } \\
\mathrm{CF}\end{array}$ \\
\hline \multirow{3}{*}{1.} & \multirow{3}{*}{$\begin{array}{l}\text { Rentang } \\
\text { Usia }\end{array}$} & a. Usia ibu $\leq 20$ tahun & 0.6 \\
\hline & & b. Usia ibu 21-35 tahun & 0.0 \\
\hline & & c. Usia ibu $>35$ tahun & 0.7 \\
\hline \multirow[b]{2}{*}{2.} & \multirow{2}{*}{$\begin{array}{c}\text { Kehamilan } \\
\text { ke- }\end{array}$} & a. Kehamilan pertama & 0.6 \\
\hline & & $\begin{array}{l}\text { b. Kehamilan kedua atau } \\
\text { lebih }\end{array}$ & 0.4 \\
\hline \multirow{2}{*}{3.} & \multirow{2}{*}{$\begin{array}{c}\text { Jarak } \\
\text { Hamil } \\
\end{array}$} & a.Jarak hamil < 24 bulan & 0.0 \\
\hline & & b. Jarak hamil > 24 bulan & -0.2 \\
\hline \multirow{2}{*}{4.} & \multirow{2}{*}{$\begin{array}{c}\text { Jenis } \\
\text { Kehamilan }\end{array}$} & a. Kehamilan tunggal & -0.2 \\
\hline & & b. Kehamilan kembar & 0.6 \\
\hline \multirow{5}{*}{5.} & \multirow{5}{*}{$\begin{array}{l}\text { Riwayat } \\
\text { Penyakit }\end{array}$} & $\begin{array}{l}\text { a. Memiliki riwayat/ } \\
\text { keturunan preeklampsia }\end{array}$ & 0.7 \\
\hline & & $\begin{array}{l}\text { b. Memiliki riwayat/ } \\
\text { keturunan hipertensi }\end{array}$ & 0.7 \\
\hline & & $\begin{array}{l}\text { c. Memiliki riwayat/ } \\
\text { keturunan DM }\end{array}$ & 0.5 \\
\hline & & $\begin{array}{l}\text { d. Memiliki riwayat } \\
\text { gangguan imun (systemic } \\
\text { lupus erythematosus/SLE) }\end{array}$ & 0.6 \\
\hline & & $\begin{array}{l}\text { e. Memiliki riwayat akseptor } \\
\text { KB }\end{array}$ & -0.1 \\
\hline \multirow{2}{*}{6.} & \multirow{2}{*}{$\begin{array}{l}\text { Indeks } \\
\text { Massa } \\
\text { Tubuh }\end{array}$} & $\begin{array}{l}\text { a. IMT (Indeks Massa } \\
\text { Tubuh) } \geq 25\end{array}$ & 0.6 \\
\hline & & $\begin{array}{l}\text { b. IMT (Indeks Massa } \\
\text { Tubuh) }<25\end{array}$ & 0.2 \\
\hline \multirow{6}{*}{7.} & \multirow{6}{*}{$\begin{array}{c}\text { Tekanan } \\
\text { Darah }\end{array}$} & $\begin{array}{l}\text { a. } \mathrm{TD}<120 / 80 \mathrm{mmHg} \text { pada } \\
<20 \text { minggu usia kehamilan }\end{array}$ & -0.7 \\
\hline & & $\begin{array}{l}\text { b. TD } 120 / 80-140 / 90 \mathrm{mmHg} \\
\text { pada }<20 \text { minggu usia } \\
\text { kehamilan }\end{array}$ & 0.4 \\
\hline & & $\begin{array}{l}\text { c. TD }>140 / 90 \mathrm{mmHg} \text { pada } \\
<20 \text { minggu usia kehamilan }\end{array}$ & 0.7 \\
\hline & & $\begin{array}{l}\text { d. TD }<120 / 80 \mathrm{mmHg} \text { pada } \\
>20 \text { minggu usia kehamilan }\end{array}$ & -0.8 \\
\hline & & $\begin{array}{l}\text { e. TD 120/80-140/90 mmHg } \\
\text { pada }>20 \text { minggu usia } \\
\text { kehamilan }\end{array}$ & 0.6 \\
\hline & & $\begin{array}{l}\text { f. TD >140/90 mmHg pada } \\
>20 \text { minggu usia kehamilan }\end{array}$ & 0.9 \\
\hline \multirow{6}{*}{8.} & \multirow{6}{*}{ Gejala } & a. Nyeri kepala berat & 0.8 \\
\hline & & b. Nyeri ulu hati & 0.7 \\
\hline & & $\begin{array}{l}\text { c. Gangguan penglihatan } \\
\text { (kabur, skotoma) }\end{array}$ & 0.8 \\
\hline & & d. Depresi/stress & 0.6 \\
\hline & & e. Sulit bernafas & 0.6 \\
\hline & & $\begin{array}{l}\text { f. Gerakan bayi lemah } \\
\text { (gerakan tendangan harian } \\
\text { bayi) }\end{array}$ & 0.5 \\
\hline
\end{tabular}

Adapun tahapan untuk melakukan perhitungan pada metode Certainty Factor yaitu :

$>$ Tentukan nilai CF Pakar $\{\mathrm{CF}(\mathrm{H})\}$ dan $\mathrm{CF}$ Pengguna $\{\mathrm{CF}(\mathrm{E})\}$ berdasarkan Tabel 1.

$>$ Lakukan perhitungan nilai CF-nya dengan mengalikan antara nilai $\mathrm{CF}$ pakar $\{\mathrm{CF}(\mathrm{H})\}$ dan nilai $C F$ pengguna $\{\mathrm{CF}(\mathrm{E})\}$

> kombinasikan setiap 2 nilai CF sesuai dengan aturan Mc.Allister. Lakukan pengulangan pengkombinasian sampai gejala terkahir yang dipilih.

> Hasil dari nilai CF kombinasi terakhir yang didapatkan dikalikan dengan $100 \%$. Sehingga jawaban yang didapatkan oleh pengguna bentuk persentase.

Contoh perhitungan Manual contoh kasus 1

a. Langkah 1: Penentuan Nilai CF Pakar (CF(h)) dan CF User (CF(e)).

1. Usia ibu 21-35 tahun. $(\mathrm{CF}(\mathrm{e}))_{1}=0.0$

2. Kehamilan Kedua atau Lebih, $(\mathrm{CF}(\mathrm{e}))_{2}=$ 0.4

3. Jarak hamil $\geq 24$ bulan, $(\mathrm{CF}(\mathrm{e}))_{3}=-0.2$

4. Kehamilan Tunggal, $(\mathrm{CF}(\mathrm{e}))_{4}=-0.2$.

5. Memiliki riwayat/ keturunan preeclampsia, $(\mathrm{CF}(\mathrm{e}))_{5}=0.7$

6. Memiliki riwayat/ keturunan Hipertensi. $(\mathrm{CF}(\mathrm{e}))_{6}=0.7$

7. Indeks Massa Tubuh $<25 .(\mathrm{CF}(\mathrm{e}))_{7}=0.2$

8. Tekanan Darah $>140 / 90 \mathrm{mmHg}$ pada $<20$ minggu usia kehamilan. $(\mathrm{CF}(\mathrm{e}))_{8}=0.7$

9. Tekanan darah $>140 / 90 \mathrm{mmHg}$ pada $>20$ minggu usia kehamilan. $(\mathrm{CF}(\mathrm{e}))_{9}=0.9$

10. Gangguan penglihatan (kabur,scotoma). $(\mathrm{CF}(\mathrm{e}))_{10}=0.8$

11. Depresi/ Stress. $(\mathrm{CF}(\mathrm{e}))_{11}=0.6$

12. Sulit bernafas. $(\mathrm{CF}(\mathrm{e}))_{12}=0.6$

Penentuan nilai $\mathrm{CF}(\mathrm{h})$ masing-masing parameter sebagai berikut.

1. $\mathrm{CF}(\mathrm{h})_{1}=\mathrm{CF}(\mathrm{h})$ Rentang Usia $=0.7$

2. $\mathrm{CF}(\mathrm{h})_{2}=\mathrm{CF}(\mathrm{h})$ Kehamilan ke $=0.6$

3. $\mathrm{CF}(\mathrm{h})_{3}=\mathrm{CF}(\mathrm{h})$ Jarak Hamil $=0.0$

4. $\mathrm{CF}(\mathrm{h})_{4}=\mathrm{CF}(\mathrm{h})$ Jenis Kehamilan $=0.6$

5. $\mathrm{CF}(\mathrm{h})_{5}=\mathrm{CF}(\mathrm{h})$ Riwayat Penyakit $=0.7$

6. $\mathrm{CF}(\mathrm{h})_{6}=\mathrm{CF}(\mathrm{h})$ Indeks Massa Tubuh $=0.6$

7. $\mathrm{CF}(\mathrm{h})_{7}=\mathrm{CF}(\mathrm{h})$ Tekanan Darah $=0.9$

8. $\mathrm{CF}(\mathrm{h})_{8}=\mathrm{CF}(\mathrm{h})$ Gejala $=0.8$

b. Langkah 2 Perkalian Nilai $\mathrm{CF}(\mathrm{h})$ dan $\mathrm{CF}(\mathrm{e})$.

1. $\mathrm{CF}(\mathrm{h}, \mathrm{e})_{1}=\mathrm{CF}(\mathrm{h})_{1} \times \mathrm{CF}(\mathrm{e})_{1}=0.0 \times 0.7=0.0$

2. $\mathrm{CF}(\mathrm{h}, \mathrm{e})_{2}=\mathrm{CF}(\mathrm{h})_{2} \times \mathrm{CF}(\mathrm{e})_{2}=0.4 \times 0.6=$ 0.24 
3. $\mathrm{CF}(\mathrm{h}, \mathrm{e})_{3}=\mathrm{CF}(\mathrm{h})_{3} \times \mathrm{CF}(\mathrm{e})_{3}=-0.2 \times 0.0=0.0$

4. $\mathrm{CF}(\mathrm{h}, \mathrm{e})_{4}=\mathrm{CF}(\mathrm{h})_{4} \times \mathrm{CF}(\mathrm{e})_{4}=-0.2 \times 0.6=-$ 0.12

Dan seterusnya untuk semua gejalan yang dipilih sampai gejalan ke 12

5. $\mathrm{CF}(\mathrm{h}, \mathrm{e})_{12}=\mathrm{CF}(\mathrm{h})_{8} \times \mathrm{CF}(\mathrm{e})_{12}=0.6 \times 0.8=$ 0.48

c. Langkah 3: Mengkombinasikan setiap 2 nilai $\mathrm{CF}(\mathrm{h}, \mathrm{e})_{\mathrm{n}}$ berdasarkan pada aturan aturan tabel

2.

1. $\mathrm{CFC}_{1}=$ kedua nilai positif $\left(\mathrm{CF}(\mathrm{h}, \mathrm{e})_{1}\right.$ dan $\left.\mathrm{CF}(\mathrm{h}, \mathrm{e})_{2}\right)$ $=0.0+0.24 \times(1-0.0)=0.24$

2. $\mathrm{CFC}_{2}=$ kedua nilai positif $=0.24+0.0 \times(1-0.24)=0.24$

3. $\mathrm{CFC}_{3}=$ salah satu nilai positif $\left(\mathrm{CFC}_{2}\right.$ positif sedangkan $\mathrm{CF}(\mathrm{h}, \mathrm{e})_{4}$ negatif ) $=\frac{0.24+(-0.12)}{1-\min (|0.24|,|-0.12|)}=0.136363636$ Dan seterusnya dikombinasikan semua nilai CF sampai CF (h,e) 12 .

4. $\mathrm{CFC}_{11}=$ kedua nilai positif $=0.997457676+0.48 \times(1-0.997457676)$ $\mathrm{CFC}_{11}=$ Certainty Factor $=0.998677992$

Nilai Certainty Factor (CF) untuk kasus ini adalah 99,86 \%. Keputusan kasus ini adalah Preklampsia. Sistem memutuskan suatu kasus berdasarkan nilai batas CF, jika besar dari $95,62 \%$ maka termasuk preklamsia dan jika kecil sama dengan 95,62 maka termasuk hipertensi dalam kehamilan tanpa resiko preeklampsia. Nilai batas ini didapatkan dari 14 data latih.

\section{Hasil dan Pembahasan}

Adapun cara penggunaan sistem monitoring kondisi kehamilan untuk deteksi dini preklampsia yaitu Ibu hamil memasang alat ukur tensimeter pada lengan kemudian memompa tekanan pada manset sampai tercapai tekanan $180 \mathrm{mmHg}$ yang terlihat pada LCD. Sensor tekanan akan mendapatkan sinyal yang selanjutnya difilter oleh High pass Butterworth. Sinyal hasil filter akan diproses pada arduino sehingga akan didapatkan nilai tekanan darah sistolik dan diastolic. Nilai tekanan darah akan ditampilkan pada Handphone android dan LCD.

Selanjutnya ibu hamil diminta membuka aplikasi sistem pakar deteksi preeklampsia. Aplikasi akan mengarahkan ibu hamil dengan memberikan kategori tekanan darah tinggi atau normal atau sedang. Selanjutnya aplikasi akan menanyakan apakah ibu hamil merasakan faktor gejala dan fator resiko yang ditampilkan. Jika ibu hamil memiliki tekanan darah normal dan tidak satu pun merasakan faktor gejala dan resiko maka diasumsikan ibu hamil dalam kondisi normal. Sebaliknya, jika ibu hamil memiliki tekanan darah tinggi dan ada merasakan faktor gejala dan faktor resiko maka ibu hamil diminta mengisi angket. Berdasarkan data-data tersebut sistem pakar certainty Factor akan memberi nilai kemungkinan apakah si Ibu hamil menderita preklamsia, atau hipertensi kehamilan tanpa resiko preklamsi. Jika nilai kemungkinan preklamsia tinggi maka sistem merekomendasikan ibu hamil untuk konsultasi ke dokter. Tampilan aplikasi pada smartphone android dapat dilihat pada gambar 4 .

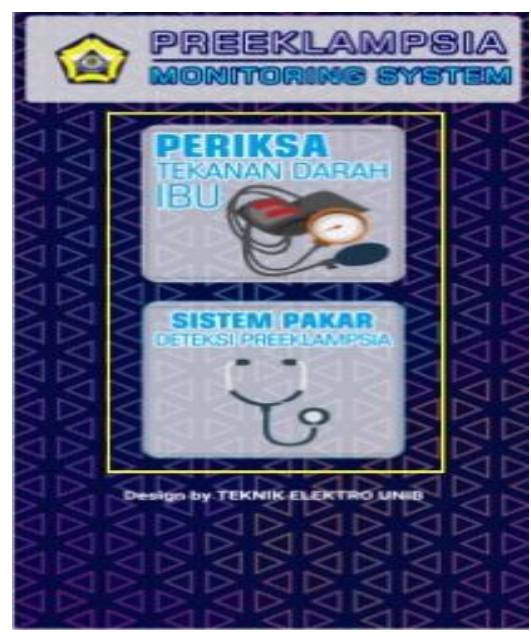

Gambar 4. Tampilan aplikasi sistem monitoring preklampsia

\subsection{Hasil Perancangan Tensimeter digital}

Bentuk fisik tensimeter digital yang dirancang seperti pada gambar 5. Hasil pembacaan ditampilkan pada aplikasi smartphone android dan LCD $16 \times 2$.

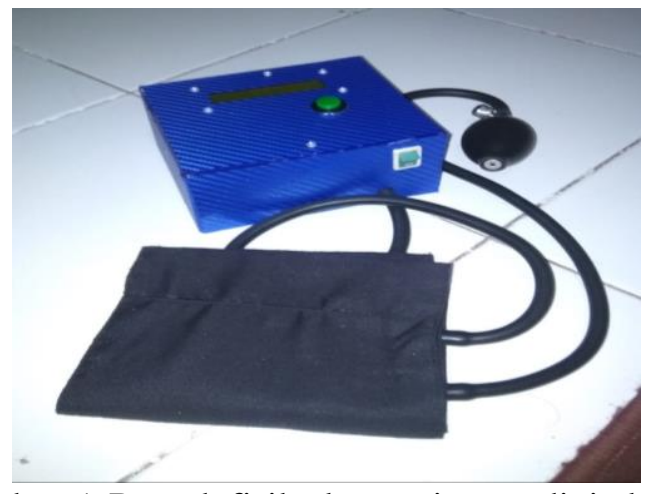

Gambar 5. Bentuk fisik alat tensimeter digital yang dirancang. 
Untuk menguji tensimeter yang dirancang, digunakan tensimeter aneroid (manual) sebagai referensi dan tensimeter digital sebagai pembanding. Perbandingan hsil pengukuran tiga tensimeter tersebut dinyatakan dalam selisih pembacaan dan Galat pengukuran seperti pada Tabel 4.

Tabel 4. Hasil pengukuran tensimeter yang

dirancang dengan 2 tensimeter pembanding

\begin{tabular}{|l|c|c|c|c|}
\hline \multirow{2}{*}{ Perbandingan } & \multicolumn{2}{|c|}{$\begin{array}{c}\text { Rata-rata selisih } \\
\text { pengukuran }\end{array}$} & \multicolumn{2}{c|}{$\begin{array}{c}\text { Galat } \\
\text { Pengukuran }\end{array}$} \\
\cline { 2 - 5 } & $\begin{array}{c}\text { SBP } \\
(\mathrm{mmHg})\end{array}$ & $\begin{array}{c}\text { DBP } \\
(\mathrm{mmHg})\end{array}$ & $\begin{array}{c}\text { SBP } \\
\%\end{array}$ & $\begin{array}{c}\text { DBP } \\
\%\end{array}$ \\
\hline $\begin{array}{l}\text { tensimeter } \\
\text { rancangan } \\
\text { terhadap } \\
\text { aneroid }\end{array}$ & 7,05 & 10,15 & 6,24 & 13,13 \\
\hline $\begin{array}{l}\text { Tensimeter } \\
\begin{array}{l}\text { Digital } \\
\text { terhadap } \\
\text { aneroid }\end{array}\end{array}$ & 9,26 & 7,57 & 8,57 & 9,5 \\
\hline $\begin{array}{l}\text { Tensimeter } \\
\text { Rancangan } \\
\text { terhadap } \\
\text { Digital }\end{array}$ & 12,75 & 9,85 & 10,69 & 14,14 \\
\hline
\end{tabular}

Metoda osilometrik digunakan pada perancangan tensimeter digital komersil karena keandalannya, tetapi tidak mampu memprediksi tekanan darah seakurat metoda auskultasi [10]. Tabel 4 menunjukan bahwa pada pembacaan tekanan sistolik tensimeter yang dirancang memiliki selisih pengukuran yang lebih kecil dibandingkan tensimeter digital yang menjadi pembanding. Sedangkan tensimeter digital pembanding memiliki selisih pembacaan yang lebih kecil untuk tekanan diastolik. Dengan kata lain tensimeter yang dirancang lebih akurat pada pengukuran sistolik sedangkan tensimeter digital pembanding lebih akurat pada tekanan diastolik.

Hasil pembacaan nilai tekanan sistolik dan diastolik sangat ditentukan oleh metoda atau algoritma penentuan kapan terjadi tekanan tersebut. Perancang tensimeter digital dapat menggunakan metoda yang berbeda sehingga memberikan hasil pengukuran yang juga berbeda. Untuk mendapatkan hasil yang akurat pada tekanan sistolik dan diastolic pengguna harus dalam posisi diam. Keakuratan tergantung pada bagaimana manset dililitkan disekeliling tangan pasien dan kepekaan sensor tekanan, sedikit pergerakan pengguna dapat mengubah nilainya secara signifikan.
Menemukan nilai tekanan yang benar cukup sulit karena ketergantungan pada amplitude gelombang yang berubah-rubah selama pengukuran. Jika pengguna tetap diam dan memakai manset dengan benar maka data yang diukur memberikan hasil yang sama dengan tensimeter aneroid (selisih $0 \mathrm{mmHg}$ ) tetapi jika tidak, maka selisih pembacaan sampai $17 \mathrm{mmHg}$. Oleh karena itu perlu diperhatikan pemilihan sensor yang tepat dan kehati-hatian selama proses pengukuran.

\subsection{Hasil Perancangan sistem pakar}

Pengujian aplikasi terbagi menjadi 2 bagian. Bagian pertama melakukan pengujian fungsional sistem dengan cara menguji semua fungsi-fungsi yang terdapat dalam aplikasi seperti fungsi button, scroll dan checkbox. Bagian kedua menguji akurasi sistem dengan cara membandingkan hasil keputusan pakar dengan hasil keputusan yang didapatkan dari aplikasi yang dirancang. Tampilan aplikasi sistem pakar dapat dilihat pada gambar 6 dan pengujian fungsional dapat dilihat pada table 5 .
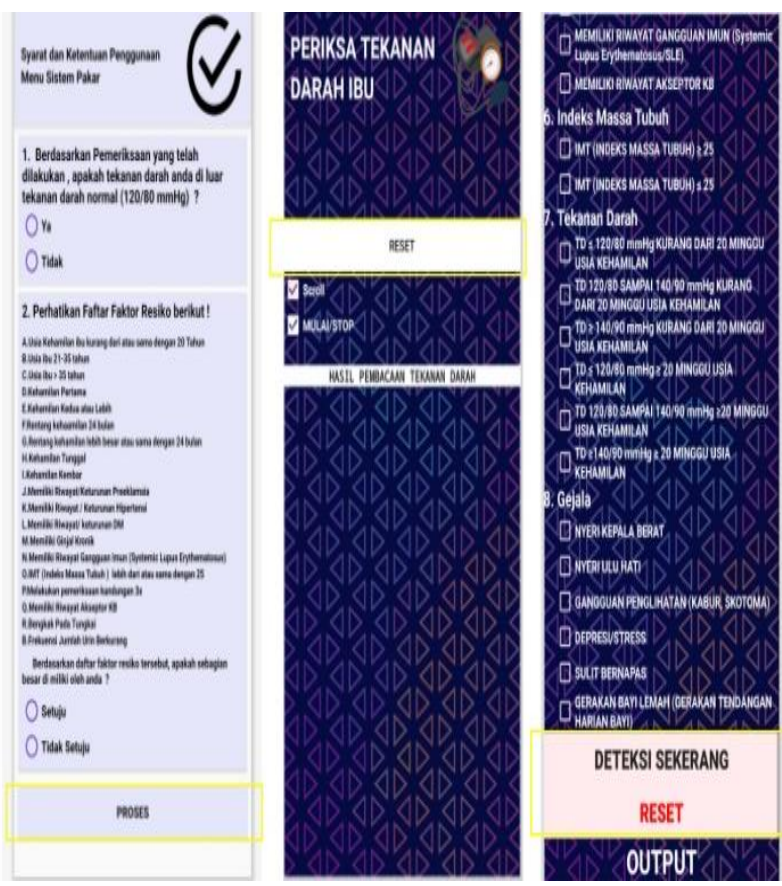

Gambar 6. Tampilan Aplikasi Sistem Pakar 
Table 5. pengujian fungsionalitas aplikasi

\begin{tabular}{|c|c|c|c|c|}
\hline No & $\begin{array}{l}\text { Komponen } \\
\text { Pengujian }\end{array}$ & Input & Output & Status \\
\hline 1 & $\begin{array}{l}\text { Fungsi } \\
\text { Checkbox }\end{array}$ & $\begin{array}{l}\text { Mencekli } \\
\text { st pilihan }\end{array}$ & $\begin{array}{l}\text { dapat dipilih } \\
\text { dan } \\
\text { ditampilkan } \\
\text { sesuai yang } \\
\text { diisikan. }\end{array}$ & Berhasil \\
\hline 2 & $\begin{array}{l}\text { Fungsi } \\
\text { Button }\end{array}$ & $\begin{array}{l}\text { Menekan } \\
\text { tombol } \\
\text { fungsi } \\
\text { seperti } \\
\text { tombol } \\
\text { "lanjut", } \\
\text { "kembali } \\
\text { "dan } \\
\text { "keluar" }\end{array}$ & $\begin{array}{l}\text { Tombol } \\
\text { "lanjut" akan } \\
\text { menampilkan } \\
\text { halaman } \\
\text { berikutnya, } \\
\text { tombol } \\
\text { "kembali" } \\
\text { menampilkan } \\
\text { halaman } \\
\text { sebelumnya } \\
\text { dan tombl } \\
\text { "keluar" untuk } \\
\text { keluar dari } \\
\text { aplikasi }\end{array}$ & Berhasil \\
\hline 3 & $\begin{array}{l}\text { Fungsi } \\
\text { Scroll }\end{array}$ & $\begin{array}{l}\text { Mengges } \\
\text { er } \\
\text { halaman } \\
\text { tampilan } \\
\text { ke atas } \\
\text { dan ke } \\
\text { bawah } \\
\text { pada } \\
\text { setiap } \\
\text { halaman } \\
\text { yang } \\
\text { bersangk } \\
\text { utan }\end{array}$ & $\begin{array}{l}\text { Halaman } \\
\text { tampilan dapat } \\
\text { digeser ke atas } \\
\text { dan ke bawah } \\
\text { dengan baik }\end{array}$ & Berhasil \\
\hline
\end{tabular}

Tabel 5 menunjukan bahwa semua aplikasi yang dirancang berfungsi dengan baik sesuai yang diharapkan. Pengujian selanjutnya adalah pengujian kebenaran sistem pakar yang dirancang dalam mengdiagnosa gejala dan factor resiko yang dimiliki oleh pengguna. Diagnosa sistem dibandingkan dengan diagnose dokter. Jika terdapat kesamaan diagnose maka dianggap sistem benar dan jika berbeda maka sistem salah. Akurasi sistem adalah persentase dari rasio jumlah benar terhadap jumlah kasus uji. Adapaun data hasil pengujian 32 kasus dapat dilihat pada tabel 6.
Tabel 6. Pengujian kasus dan perbandingan hasil diagnose

\begin{tabular}{|c|c|c|c|c|c|}
\hline No & Gejala & $\begin{array}{c}\text { Diagnosa } \\
\text { Pakar/Dokter }\end{array}$ & $\begin{array}{c}\text { Nilai } \\
\mathrm{CF}\end{array}$ & $\begin{array}{l}\text { Keputusan } \\
\text { Sistem }\end{array}$ & $\begin{array}{l}\text { Keter } \\
\text { anga } \\
\mathrm{n}\end{array}$ \\
\hline 1 & $\begin{array}{l}1 \mathrm{a}, 2 \mathrm{a}, \\
4 \mathrm{a}, 6 \mathrm{~b}, \\
7 \mathrm{f}\end{array}$ & $\begin{array}{c}\text { Hipertensi } \\
\text { Tanpa Resiko } \\
\text { Preeklampsia }\end{array}$ & 94.87 & $\begin{array}{c}\text { Hipertensi } \\
\text { Tanpa Resiko } \\
\text { Preeklampsia }\end{array}$ & Sama \\
\hline 2 & $\begin{array}{l}1 \mathrm{~b}, 7 \mathrm{f}, \\
5 \mathrm{a}, 3 \mathrm{~b}, \\
2 \mathrm{~b}, 5 \mathrm{e}, \\
6 \mathrm{a}\end{array}$ & Preeklampsia & 94.24 & $\begin{array}{c}\text { Hipertensi } \\
\text { Tanpa Resiko } \\
\text { Preeklampsia }\end{array}$ & Beda \\
\hline 3 & $\begin{array}{l}1 \mathrm{~b}, 8 \mathrm{c}, \\
8 \mathrm{~b}, 8 \mathrm{a}, \\
3 \mathrm{~b}, 2 \mathrm{~b}, \\
4 \mathrm{a}, 7 \mathrm{f}\end{array}$ & Preeklampsia & 99.06 & Preeklampsia & Sama \\
\hline 4 & $\begin{array}{l}1 \mathrm{~b}, 7 \mathrm{f}, \\
8 \mathrm{a}, 8 \mathrm{~b}, \\
4 \mathrm{a}\end{array}$ & Preeklampsia & 96.57 & Preeklampsia & Sama \\
\hline 5 & $\begin{array}{l}1 \mathrm{c}, 8 \mathrm{a} 2 \\
\mathrm{~b}, 3 \mathrm{~b}, 7 \\
\mathrm{e}, 4 \mathrm{a}, 5 \\
\mathrm{e}, 6 \mathrm{a}\end{array}$ & Preeklampsia & 97.92 & Preeklampsia & Sama \\
\hline 6 & $\begin{array}{l}1 \mathrm{c}, 7 \mathrm{f} \\
4 \mathrm{a}\end{array}$ & $\begin{array}{c}\text { Hipertensi } \\
\text { Tanpa Resiko } \\
\text { Preeklampsia }\end{array}$ & 88.98 & $\begin{array}{c}\text { Hipertensi } \\
\text { Tanpa Resiko } \\
\text { Preeklampsia }\end{array}$ & Sama \\
\hline 7 & $\begin{array}{l}1 \mathrm{c}, 5 \mathrm{e}, \\
2 \mathrm{~b}, 3 \mathrm{~b}, \\
7 \mathrm{f}, 6 \mathrm{a}, \\
8 \mathrm{a}, 4 \mathrm{a}\end{array}$ & Preeklampsia & 97.92 & Preeklampsia & Sama \\
\hline 8 & $\begin{array}{l}8 \mathrm{a}, 1 \mathrm{~b}, \\
7 \mathrm{f}, 8 \mathrm{c}, \\
4 \mathrm{a}, 6 \mathrm{a}\end{array}$ & Preeklampsia & 98.20 & Preeklampsia & Sama \\
\hline 9 & $\begin{array}{l}1 \mathrm{~b}, 8 \mathrm{a}, \\
7 \mathrm{f}, 6 \mathrm{a}\end{array}$ & $\begin{array}{c}\text { Hipertensi } \\
\text { Tanpa Resiko } \\
\text { Preeklampsia }\end{array}$ & 95.62 & $\begin{array}{c}\text { Hipertensi } \\
\text { Tanpa Resiko } \\
\text { Preeklampsia }\end{array}$ & Sama \\
\hline 10 & $\begin{array}{l}1 \mathrm{a}, 2 \mathrm{a}, \\
4 \mathrm{a}, 5 \mathrm{a}, \\
6 \mathrm{~b}, 7 \mathrm{f}, \\
8 \mathrm{a}, 8 \mathrm{~b}, \\
8 \mathrm{c}\end{array}$ & Preeklampsia & 99.79 & Preeklampsia & Sama \\
\hline 11 & $\begin{array}{l}1 \mathrm{~b}, 2 \mathrm{~b}, \\
3 \mathrm{a}, 4 \mathrm{a}, \\
5 \mathrm{a}, 5 \mathrm{~b}, \\
6 \mathrm{a}, 7 \mathrm{~b}, \\
7 \mathrm{f}, 8 \mathrm{c}, \\
8 \mathrm{~d}, 8 \mathrm{e}\end{array}$ & Preeklampsia & 99.86 & Preeklampsia & Sama \\
\hline 12 & $\begin{array}{l}1 \mathrm{~b}, 2 \mathrm{~b}, \\
3 \mathrm{~b}, \\
4 \mathrm{a}, 5 \mathrm{a}, \\
5 \mathrm{~b}, \\
5 \mathrm{e}, 6 \mathrm{a}, \\
7 \mathrm{e}, 8 \mathrm{f}\end{array}$ & Preeklampsia & 98.23 & Preeklampsia & Sama \\
\hline 13 & $\begin{array}{l}1 \mathrm{~b}, \\
2 \mathrm{~b}, \\
3 \mathrm{~b}, \\
4 \mathrm{a}, 5 \mathrm{a}, \\
5 \mathrm{~b}, \\
6 \mathrm{~b}, \\
77 \mathrm{~b}, \\
7 \mathrm{e}, \\
8 \mathrm{a}, 8 \mathrm{f}\end{array}$ & Preeklampsia & 99.78 & Preeklampsia & Sama \\
\hline
\end{tabular}




\begin{tabular}{|c|c|c|c|c|c|}
\hline 14 & $\begin{array}{l}1 \mathrm{~b}, 3 \mathrm{~b} \\
4 \mathrm{a}, 5 \mathrm{a} \\
5 \mathrm{~b}, 6 \mathrm{a}, \\
7 \mathrm{e}, 8 \mathrm{a}\end{array}$ & $\begin{array}{c}\text { Hipertensi } \\
\text { Tanpa } \\
\text { Resiko } \\
\text { Preeklampsia } \\
\end{array}$ & 98.70 & Preeklampsia & Beda \\
\hline 15 & $\begin{array}{c}1 \mathrm{a}, 2 \mathrm{a}, \\
3 \mathrm{a}, 4 \mathrm{~b}, 5 \mathrm{a}, \\
6 \mathrm{a}, 7 \mathrm{e}, 8 \mathrm{a}\end{array}$ & Preeklampsia & 99.46 & Preeklampsia & Sama \\
\hline 16 & $\begin{array}{c}1 \mathrm{a}, 2 \mathrm{a}, \\
3 \mathrm{a}, 4 \mathrm{a}, 5 \mathrm{a}, \\
6 \mathrm{a}, 7 \mathrm{e}, 8 \mathrm{c}\end{array}$ & Preeklampsia & 99.05 & Preeklampsia & Sama \\
\hline 17 & $\begin{array}{c}1 \mathrm{c}, 2 \mathrm{~b}, 3 \mathrm{~b} \\
5 \mathrm{a}, 6 \mathrm{~b}, 7 \mathrm{f} \\
8 \mathrm{~b}\end{array}$ & Preeklampsia & 98.54 & Preeklampsia & Sama \\
\hline 18 & $\begin{array}{l}1 \mathrm{a}, 2 \mathrm{a}, 4 \mathrm{a}, \\
5 \mathrm{a}, 6 \mathrm{~b}, 7 \mathrm{~b}\end{array}$ & $\begin{array}{c}\text { Hipertensi } \\
\text { Tanpa } \\
\text { Resiko } \\
\text { Preeklampsia }\end{array}$ & 96.91 & Preeklampsia & Beda \\
\hline 19 & $\begin{array}{l}1 \mathrm{~b}, 2 \mathrm{~b}, 3 \mathrm{~b} \\
4 \mathrm{~b}, 5 \mathrm{a}, 6 \mathrm{a}\end{array}$ & Preeklampsia & 98.50 & Preeklampsia & Sama \\
\hline 20 & $\begin{array}{c}\text { 1a,2a,4a, } \\
\text { 6a,7e, }\end{array}$ & $\begin{array}{c}\text { Hipertensi } \\
\text { Tanpa } \\
\text { Resiko } \\
\text { Preeklampsia } \\
\end{array}$ & 94.87 & $\begin{array}{c}\text { Hipertensi } \\
\text { Tanpa } \\
\text { Resiko } \\
\text { Preeklampsia } \\
\end{array}$ & Sama \\
\hline 21 & $\begin{array}{l}1 \mathrm{~b}, 2 \mathrm{~b}, 3 \mathrm{~b}, \\
4 \mathrm{a}, 5 \mathrm{a}, 5 \mathrm{e} \\
6 \mathrm{a}, 7 \mathrm{~b}, 7 \mathrm{e}\end{array}$ & Preeklampsia & 97.86 & Preeklampsia & Sama \\
\hline 22 & $\begin{array}{c}1 \mathrm{c}, 2 \mathrm{~b}, 4 \mathrm{a} \\
5 \mathrm{a}, 6 \mathrm{~b}, 7 \mathrm{f} \\
8 \mathrm{a}, 8 \mathrm{~b}\end{array}$ & Preeklampsia & 99.40 & Preeklampsia & Sama \\
\hline 23 & & & & & \\
\hline 24 & $\begin{array}{c}1 \mathrm{a}, \\
2 \mathrm{a}, 4 \mathrm{a}, 5 \mathrm{a}, \\
6 \mathrm{a}, 7 \mathrm{e}, 8 \mathrm{a}\end{array}$ & Preeklampsia & 99,05 & Preeklampsia & Sama \\
\hline 25 & $\begin{array}{c}1 b, 2 a, 4 a, \\
5 a, 5 d, 6 b, \\
73\end{array}$ & Preeklampsia & 99,05 & Preeklampsia & Sama \\
\hline 26 & $\begin{array}{c}1 a, \\
2 a, 5 c, 6 a, \\
7 c\end{array}$ & $\begin{array}{l}\text { Hipertensi } \\
\text { Tanpa } \\
\text { Resiko } \\
\text { Preeklampsia } \\
\end{array}$ & 94,28 & $\begin{array}{l}\text { Hipertensi } \\
\text { Tanpa } \\
\text { Resiko } \\
\text { Preeklampsia } \\
\end{array}$ & Sama \\
\hline 27 & $\begin{array}{c}1 \mathrm{c}, 2 \mathrm{~b}, 3 \mathrm{~b} \\
4 \mathrm{a}, 5 \mathrm{e}, 6 \mathrm{a} \\
7 \mathrm{e}, 8 \mathrm{a}\end{array}$ & Preeklampsia & 98,57 & Preeklampsia & Sama \\
\hline 28 & $\begin{array}{c}1 c, 2 b, 3 b \\
4 a, 5 b, 6 b, \\
7 e, 8 a\end{array}$ & Preeklampsia & 98,64 & Preeklampsia & Sama \\
\hline 29 & $\begin{array}{c}1 c, 2 a, 4 a, \\
7 e, 8 d\end{array}$ & Preeklampsia & 99,74 & Preeklampsia & Sama \\
\hline 30 & $\begin{array}{c}1 \mathrm{~b}, 2 \mathrm{a}, 4 \mathrm{a}, \\
7 \mathrm{e}, 8 \mathrm{~d}\end{array}$ & Preeklampsia & 97,33 & Preeklampsia & Sama \\
\hline 31 & $\begin{array}{c}1 b, 2 b, 3 b, \\
4 a, 6 a, 7 c\end{array}$ & $\begin{array}{l}\text { Hipertensi } \\
\text { Tanpa } \\
\text { Resiko } \\
\text { Preeklampsia } \\
\end{array}$ & 79,54 & $\begin{array}{l}\text { Hipertensi } \\
\text { Tanpa } \\
\text { Resiko } \\
\text { Preeklampsia } \\
\end{array}$ & Sama \\
\hline 32 & $\begin{array}{l}c, 2 b, 3 b \\
5 c, 6 b, 7 a\end{array}$ & $\begin{array}{l}\text { Hipertensi } \\
\text { Tanpa } \\
\text { Resiko } \\
\text { Preeklampsia }\end{array}$ & 72,4 & $\begin{array}{l}\text { Hipertensi } \\
\text { Tanpa } \\
\text { Resiko } \\
\text { Preeklampsia }\end{array}$ & Sama \\
\hline 33 & $\begin{array}{c}1 a, 2 a, 4 a \\
5 a, 5 d, 6 b, \\
7 e\end{array}$ & Preeklampsia & 95,72 & Preeklampsia & Sama \\
\hline 34 & $\begin{array}{c}b, 2 a, 5 b, \\
4 a, 7 f, 8 a, \\
8 c\end{array}$ & Preeklampsia & 99,08 & Preeklampsia & Sama \\
\hline 35 & $\begin{array}{l}1 \mathrm{c}, 2 \mathrm{~b}, 4 \mathrm{a} \\
5 \mathrm{a}, 6 \mathrm{a}, 7 \mathrm{e}\end{array}$ & Preeklampsia & 97.26 & Preeklampsia & Sama \\
\hline
\end{tabular}

Berdasarkan tabel 6 dapat dilihat bahwa terdapat diagnosa yang sama sebanyak 32 kasus dari 35 kasus yang diujikan, maka dapat dikatakan akurasi sistem untuk data ini adalah sebesar 91,45 \%. Penelitian [11] menggunakan metoda logika fuzzy dan mendapatkan akurasi $85 \%$ yaitu 17 kasus benar dari 20 kasus yang diujikan. Penelitian [12] menggunakan metoda Naïve Bayes mendapatkan akurasi $90 \%$ yaitu 9 kasus benar dari 10 kasus yang diuji. Berdasarkan kasus-kasus yang diuji pada table 6 , jika usia ibu hamil $<20$ tahun atau $>35$ tahun dengan Tekanan darah $>140 / 90 \mathrm{mmHg}$ pada usia kehamilan > 20 minggu disertai dengan satu atau lebih gejala pada nomor 8 di tabel 3, maka kemungkian besar niai $\mathrm{CF}$ akan tinggi sehingga diagnosanya akan preklamsia.

Sistem yang telah dirancang ini dapat menjadi salah satu cara untuk mencegah preeklampsia karena jika ibu hamil diduga hipertensi dalam kehamilan tanpa resiko preklamsia, maka seharusnya itu menjadi peringatan bagi si Ibu untuk selanjutnya berhati-hati menjaga tekanan darahnya, kesehatan diri dan kondisi kehamilannya. Selain itu sistem ini juga merupakan peringatan awal dengan cara mendeteksi secara dini kemungkinan terjadi resiko preklamsia pada ibu hamil sehingga ibu tersebut disarankan untuk segera berkonsultasi ke dokter agar didapatkan pengobatan dan penanganan yang cepat dan tepat sebelum berlajut menjadi eklampsia.

\section{Kesimpulan}

Sistem monitoring kondisi kehamilan untuk deteksi preeklampsia yang telah dirancang telah dapat bekerja dengan semua fungsi aplikasi berjalan sesuai yang diharapkan dan akurasi sistem pakar sebesar $91,45 \%$. Alat ukur tekanan darah yang dirancang untuk mendukung sistem ini telah mampu bekerja dengan rata-rata selisih terhadap pengukuran tensimeter aneroid (analog) sebesar 7,05 mmHg dengan galat 6,24 $\%$ untuk tekanan sistolik dan $10,15 \mathrm{mmHg}$ dengan galat $13,13 \%$ untuk tekanan diastolik. Alat ukur 
tensimeter yang dirancang telah bekerja pada pengukuran tekanan sistolik tetapi untuk tekanan diastolik masih perlu ditingkatkan dengan cara pemilihan sensor yang tepat dan metoda penentuan tekanan yang lebih baik.

\section{Ucapan Terima Kasih}

Terima kasih disampaikan kepada Universitas Bengkulu yang telah memberikan dana penelitian pembinaan tahun 2020 dengan nomor kontrak : 2049/UN30.15/PG/2020

\section{Daftar Pustaka}

[1] Kementerian Kesehatan, laporan Survei Demografi dan Kesehatan Indonesia (SDKI)2017, Jakarta, 2018.

[2] Dinas Kesehatan Provinsi Bengkulu, Profile Kesehatan Provinsi Bengkulu 2018, Bengkulu.

[3] Perkumpulan Obstetri dan Ginekolog Indonesia (POGI), Pedoman Nasional Pelayanan Kedokteran : Diagnosis dan Tata Letak Preklamsia, 2016.

[4] Irawati, Ahmad,M dan Syarif,S,'Optimasi Sistem Pakar Deteksi Dini Preklamsia Berbasis Mobile', Jurnal Neirs dan Kebidanan, Vol 5 No2 : 159-162, 2018.

[5] O'Gorman, Neil., et al, 'Competing Risks Model In Screening For Preeclampsia By Maternal Factors And Biomarkers at 11-13 Weeks Gestation', American Journal of Obstetrics \& Gynecology, 214:103.e1-12, 2016.

[6] Zakiyah, Neily., et al, Preeclampsia Diagnosis and Treatment Options : A Review of Published Economic Assessments, Pharmaco Economics, 33:1069-1082, 2015.

[7] Sotunsa, J.O., et al, Community Health Workers' Knowledge And Practice In Relation To Pre-eclampsia in Ogun State, Nigeria: An Essential Bridge To Maternal Survival. Bio Med Central: Reproductive Health Journal, vol 3 supp2: 134-139, 2016.
[8] Arif, Abdillah., et al, Perancangan Sistem Pakar Diagnose Penyakit Kehamilan Berbasis Web. Jurnal TECHNO Nusa Mandiri, Vol 15 No 2: $115-120, .2018$

[9] Das, Subrata. Computational Business Analytics. Boca Raton: CRC Press.2014.

[10] Muhibul Haque Bhuyan. " Design and Implementaion of a Low -Cost Blood Pressure Measuring Device," 10th International Conference on Electrical and Computer Engineering 20-22 December, IEEE, 2018 , pp. 309-312

[11] Adinda Mustika N. "Sistem Pakar deteksi Dini Resiko pada Ibu Hamil Terhadap Preeklampsia Dengan Logika Fuzzy,"Skripsi, Fakultas Sains dan Teknologi Universitas Airlangga, Surabaya, 2016.

[12] Melan Handayani,, " Sistem Pakar Untuk diagnose Awal Penyait Preeklampsia Pada Ibu hamil Menggunakan Metoda Naïve Bayes”, Skripsi Sekolah Tinggi Teknologi Pelita Bangsa, Bekasi, 2018

\section{Biodata Penulis}

Fitrilina, Menyelesaikan S1 di Teknik Elektro Fakultas Teknik Universitas Andalas tahun 2005. Menamatkan S2di Teknik Elektro STEI-ITB tahun 2010. Bidang riset Telekomunikasi. Saat ini terdaftar sebagai staf pengajar di Jurusan Teknik Elektro Fakultas Teknik Universitas Bengkulu

Afriyastuti Herawati, Menyelesaikan S1 di Teknik Elektro Fakultas Teknik Universitas Andalas tahun 2004. Menamatkan S2 di Teknik Elektro STEI-ITB tahun 2010. Bidang riset Sistem tenaga Listrik. Saat ini terdaftar sebagai staf pengajar di Jurusan Teknik Elektro Fakultas Teknik Universitas Bengkulu

Nikki Aldi Massardi, Menyelesaikan S1 di Biologi Universitas Indonesia tahun 2013. Menamatkan S2 di Biomedik Universitas Indonesia tahun 2017. Bidang riset Sistem tenaga Listrik. Saat ini terdaftar sebagai staf pengajar di Program Studi S1 Kedokteran, Fakultas Kedokteran dan Ilmu Kesehatan, Universitas Bengkulu. 
Indra Agustian, menyelesaikan S1 dan S2 di Teknik Elektro dan Teknologi Informasi Universitas Gajah Mada. BIdang Riset Instrumentasi Elektronik, sistem Kendali dan Kecerdasan buatan. Saat ini terdaftar sebagai staf pengajar di Jurusan Teknik Elektro Fakultas Teknik Universitas Bengkulu

Muhammad Albbi, Menyelesaikan S1 di Prodi Teknik Elektro FT Universitas Bengkulu pada tahun 2021 